\title{
英国集落における住民主体のコミュニティショップ活動に関する研究 ーオックスフォードシャー県の14集落を対象としてー
}

\author{
ACTUAL SITUATIONS OF COMMUNITY-OWNED SHOPS IN UK VILLAGES \\ - Case studies of 14 villages in Oxfordshire county, England -
}

\author{
堀部修一*，野嶋慎二**
}

\section{Shuichi HORIBE and Shinji NOJIMA}

\begin{abstract}
This study aims to clarify key points to maintain profitability and to increase possibility of community-led projects in villages through the actual condition survey about community-owned shops in Oxfordshire, UK. The major findings are as follows.

1. Community-owned shops aims to provide various public benefits for the villages, such as community centre, social centre, local business support and eco-friendly idea.

2. Intermediate support organizations should give communities comprehensive support and advice, in a close cooperation and coordination with other organizations, to increase possibility.

3. Management system by local residents should be highly organized and divide professional work to maintain profitability.
\end{abstract}

Keywords : Village Shop, Community Initiative, Community Business, Sustainability, UK

集落商店，住民主体，コミュニティビジネス，持続可能性，英国

\section{1 研究の背景と目的}

近年、我が国では過疎化が進行し、多方面の課題を抱える集落が 多く存在する。とくに、商店や飲食店、路線バス等の日々の暮らし を支える生活機能の喪失は深刻な問題である。その中でも、商店は 買い物だけでなく、住民同士の交流や雇用の創出などの集落生活を 支える多様な役割を担っていると考えられる。つまり、商店の喪失 は、集落全体の活力および持続可能性の低下に直結すると言える。 また、豊かな自然環境や温かい人間関係を求めて、都市部からの 訪問者や移住者が増加している集落も見られ、日常的な買い物や交 流の場である商店の維持管理方法の検討は重要な課題である。

このような中、住民主体のまちづくり活動の普及も影響し、持続 可能な集落の形成に向けて、様々な住民主体の活動が全国で実施さ れている。最近では、コミュニティビジネスが一手法として注目さ れており集落でも増加している。しかし、多くの事例は活動の実現 性や継続性に課題を抱えており、その課題解決が急務である。

英国では昔から歴史や自然を大切にする文化・風習があり、多く の集落で建物や緑地等が保全され、良好な景観が維持されている。 それにより、世界的な評価も高く、コッツウォルズ地域のように世 界中から訪問者が訪れる集落も存在する。また、国民の集落に対す る憧れも強く、定年退職者や個人経営者の移住が多く見られる。

一方、我が国と同様に様々な課題を経験してきたが、集落の生活 やコミュニティの維持に対する熱意を持つ住民が多く、持続可能
な集落の形成に向けて、様々な住民主体の活動が実施されてきた。 その一つに、住民の共同運営によるコミュニティショップ（以下、 CS）の活動があり、英国で 20 年以上も継続的に実施されている。

既往研究を見ると、我が国でも「共同店」という住民の共同運営 による商店の活動実態を考察した研究1)が見られる。また、農産物 直売所の運営(2) やコミュニティバスの導入 ${ }^{3 / 4)}$ 等のコミュニティビジ ネスの実態や、その他住民主体の集落づくりのプロセス ${ }^{56)}$ を考察し た研究が見られる。英国集落については、コミュニティビジネス組 織の活動実態 ${ }^{7)}$ と共に、農村振興政策の実施実態 ${ }^{899}$ や都市農村計画 制度の変遷 ${ }^{10}$ 、コミュニティプラン政策の特徴 ${ }^{1112)}$ 等の政策に関す る研究が多く見られる。しかし、持続可能な集落形成に向けた、住 民主体のまちづくり活動の実態を考察した研究の蓄積は少ない。

本研究では、英国の県レベルの地方自治体である Oxfordshire に 位置する CS の活動実態を把握して、CS の採算性と実現性を支える 要因を明らかにする事で、持続可能な集落の形成に向けて、住民主 体で生活機能を維持する為の基礎的知見を得る事を目的とする。

研究の方法は以下の通りである。第一に、英国全体に展開寸る CS 活動の変遷と社会的背景を整理し、英国における CS の位置づけ を述べる。第二に、Oxfordshire 内の CS に着目し、その活動内容や 経営状況、運営体制等を把握して CS 活動の採算性を支える要因を 考察する。第三に、CS 準備段階の特徵や開設支援内容等を把握し て CS 活動の実現性を支える要因を考察する。
$*$ 福井大学大学院工学研究科 大学院生 . 工修

** 福井大学大学院工学研究科 教授・博士 (工学)
Graduate Student, Graduate School of Engineering, University of Fukui, M. Eng. Prof., Graduate School of Engineering, University of Fukui, Dr. Eng. 


\section{2 調査の概要}

\section{1 調査対象地の選定}

2011 年 9 月現在、265 件の CS が英国に存在する注。County 別の CS 件数上位 10 件㳅を見ると、South West と South East の County に集中している事が分かる。次に、上位 3 件の CS 累計件数注に注 目すると、Oxfordshireに比較的早い時期に開設したCSが多い。 また、それらのCountyにおいて、閉鎖した CS が 1 件もない事から、 Oxfordshire には継続年数の長い CS が多く存在すると言える。

以上より、本研究では継続年数の長いCS が多く存在する 0xfordshireの18 集落を調査対象地として選定した。

\section{2 調查の方法}

2010 年 9 月に予備調查として、 1 件の CS に聞き取り調查を実施 した。そして、2011年 9 月ー 11 月に、以下の通り第二回現地調査 を実施し、全 18 件中 14 件の CS から調查協力を得る事ができた。

1) 英国における CS 活動の変遷の把握 : CS の全国支援組織である Plunkett Foundation粱（以下、Plunkett）への聞き取りから、過去 30 年間の全国的な CS 活動の変遷の把握を行なった。

2）CS 活動の実態把握：CS 運営者への聞き取り及び目視調查から、 事業目的やサービス内容、売上額、運営体制等の把握を行なった。 また、利用建物の図面を作成し、空間特性の把握を行なった。

3） CS 準備段階の特徵の把握 : CS 運営者への聞き取りから、開設の きっかけやプロセス、資金調達方法等の把握を行なった。また、 Oxfordshire Rural Community Counci1 $1_{5}^{\text {ia }}$ ( 以下、ORCC) と Plunkett への聞き取り及び文献調查泟から、開設支援内容の把握を行なった。

聞き取った内容は、事前に作成した調查表に書き込み、音声記録 によって適宜内容を補足した。そして、その結果から必要な項目を 抽出してデータ化を行ない、分析の対象とした。

\section{3 対象集落の概要}

図 1 に、CS のある集落の位置を示す。Oxfordshire はロンドンか ら西へ約 $80 \mathrm{~km}$ に位置し、グリーンベルト ( 約 $\left.668 \mathrm{~m}^{2}\right)$ を含む良好 な自然環境や多くの歴史的な建造物群が保全されている。また、幹 線道路網や鉄道網も充実しており、企業の立地も多い。このような 地域に、大小様々な約 300 件の集落が存在する。

調查協力を得る事ができた 14 集落の特徵を見ると隽、大部分の 集落が多くの登録建造物售を持ち、保全地区注にも指定されている。 また、特別自然美観地区清に指定されている集落もあり、多くの集 落が昔からの集落景観を維持している事が分かる。さらに、集落計 画清を策定寸る集落も多く、住民の熱意や意識の高さが伺える。近 隣市町への近接性は、 $3 \mathrm{~km}$ 未満が 3 件、 $3 \mathrm{~km}$ - $5 \mathrm{~km}$ 未満が 11 件あり、 比較的スーパーや病院等のある市街地に近い集落が多い。大部分の 集落で 65 歳以上の高齢化率が $14 \%$ 以上と高い一方、25 歳未満の若 者率が $22 \%$ 以上であり、高齢者と若者の共存する集落が多い。

次に、集落内の生活機能湴を見ると、大部分の集落に主要な生活 機能が残っており、生活利便性は低くない事が分かる。しかし、施 設の老朽化や運行頻度の低下などの問題が見られる。また、「医療 施設」や「図書館」は近隣市町に依存せざるを得ない状況である。

\section{3 英国におけるCS 活動の変遷と社会的背景の整理洼}

英国では、1970 年代から郊外大型店が増え始め、1980 年代後半 に急増した。これは、サッチャー政権による、市場主義に基づく、

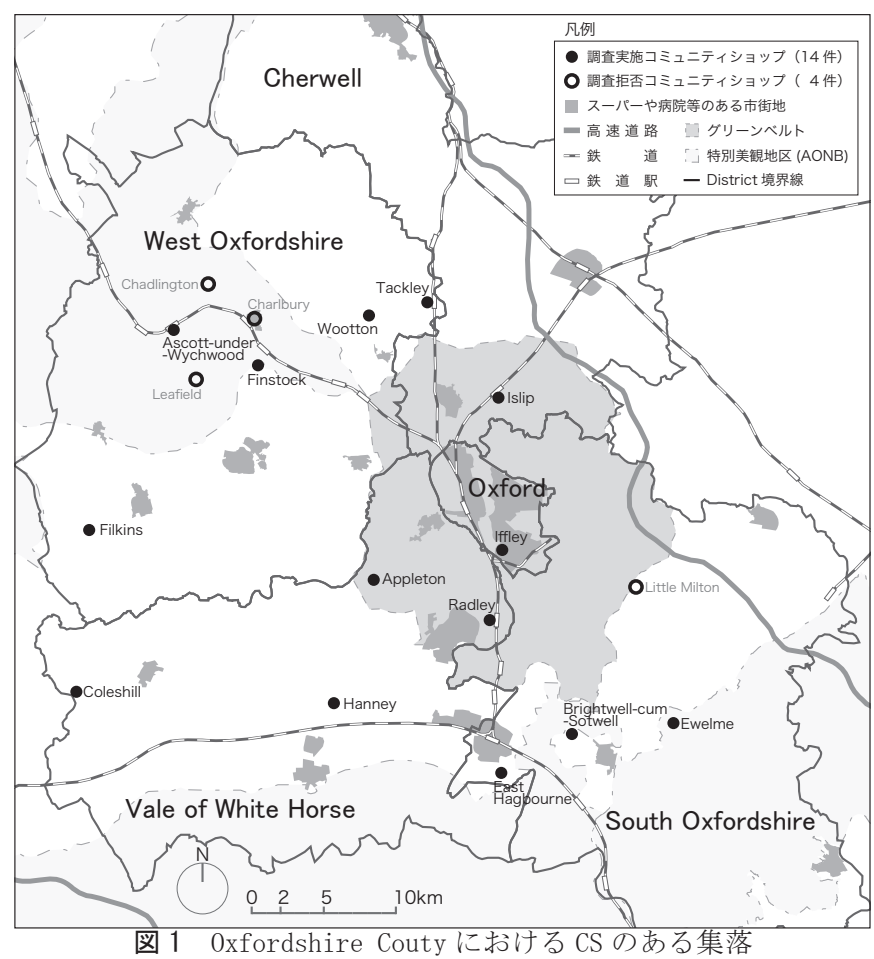

戦略的かつ局地的な土地利用の規制緩和政策が影響していると考え られ、1990 年代には、売場面積 10 万 $\mathrm{m}^{2}$ 以上のショッピングセンター も数力所で開店したと報告されている。これにより、英国各地で多 くの個人商店が閉店した。また現在も、集落で毎年約 400 件の個人 商店が閉店していると言われている。こうした中、1997 年に誕生 したブレア政権のパートナーシップ政策により、ボランタリー・セ クターの育成が推奨され、ボトムアップ型まちづくりの土缺が築か れた。一方、ブラウン政権は、郵政事業の経営難から、2008 年一 2009 年の間に英国全体で 2500 件の郵便局を閉鎖した。集落住民に とって重要な交流拠点でもあり、日常生活への影響が懸念された。

こうした社会変化の中、現在 CS として知られる活動は、1991 年 にDorset County の Halstock 集落で始まった。それ以前にも同様 の活動は多少あったが、CS という共通の定義洗はなかった。1991 年、 Halstock の商店が閉店の危機を迎えた際、住民が議論して CS 開設 を決めた。1992 年にCS を開設すると共に、理事長 Derek Smith 氏 を中心に、Village Retail Services Association(以下、ViRSA) と いうチャリティ組織を設立して、同じ問題を持つ集落の支援を始め た。ViRSA は、2000 年までに 50 件以上の CS 開設を支援した。2004 年、 ViRSA は密接に連携していたPlunkett と合併協議を行ない、数年後、 CS 支援活動をPlunkett に引き継いだ。それ以来、Plunkett が英国 唯一のCS 全国支援組織として活動している。

1991 年に英国全体で 33 件だった CS は、2011 年 9 月現在、265 件 存在する。1998 年から開設数が増加しており售、多くの郵便局が閉 鎖した 2009 年には、それを補完するように 40 件以上の CS が開設 した。過去 10 年間の年間平均開設数は 19 件である。また、英国に おけるビジネス開設後 5 年間の継続率が約 $46.8 \%$ である中、CS は 現在まで合計 8 件しか閉店しておらず、その高い継続性が注目され ている。そして、英国の協同組合や社会的企業における先駆的な成 功事例の一つとして評価されている。 
4 コミュニティショップ活動の特徵（表 1)

\section{1 幅広い公益性を持つ事業目的}

全ての CS が「各種サービスの提供」と「コミュニティの中心」 を挙げており、商店や郵便局等の基䃈サービスの提供だけでなく、 おしゃべりや情報交換など、人々の集まる交流拠点となる事を目 指している。例えば Brightwe11-cum-Sotwe11 は、顧客との積極的 な会話やカフェの設置により、誰でも訪れやすい雾囲気づくりを 試みている。また、8 件の CS が「社会的支援の提供」を挙げてお り、高齢者や障害者等に、商品の宅配や就業体験、悩夕相談等を提 供する福祉拠点となる事を目指している。例えばIffley では、養 護学校児童を招いたレジ体験や新規住民への生活アドバイス等を実 施している。その他に、「地場産業の支援」「地球環境への配慮」が 4 件ずつ見られ、地元産の生鮮食品・加工品の提供や太陽光発電の 利用など、集落内の産業支援や環境共生を目指している。例えば Ewelme では、野菜やワイン、チーズ等の多品目の厳選した地場産 品を販売している。Coleshil1 では、バイオマスボイラーの設置や エコ商品の販売を通して環境負荷の低減に取り組でいる。

以上より、CS は商店等の基礎サービスの復活だけでなく、「交流 拠点」「福祉拠点」「産業支援」「環境共生」という幅広いテーマの 公益性を持つ事業目的を掲げている事が分かり、集落の抱える多方 面の課題解決に寄与する可能性も考えられる。

\section{2 多様かつ独自性の高い商品とサービス}

5 種類以上の商品を販売する CS が 9 件あり、充実した商品展開 を行なっている。また、全てのCS が「食料品」「日用品」「地場産品」 を販売している。地場産品は、地元農家が生産する食品や住民が趣 味で作った手工芸品等の幅広い商品があり、集落ごとに多様で独自 性の高い商品が見られる。「手作り惣菜」も 7 件と多く、ボランティ アが毎朝製造するサンドウィッチやパイ等が昼食時に人気である。
サービスは、「郵便サービス」「ドライクリーニング」「商品の宅配」 が 8 件ずつと多い。事業目的で「社会的支援の提供」を挙げた CS は、 商品宅配を通じて高齢者や病人等の様子を確認している。また、「カ フェ」が 4 件あり、商店空間に余裕のある CS では、住民や来訪者 が紅茶を飲みながら会話を楽しめる場所を提供している。さらに、 「多目的スペース」が 2 件あり、定期的に地元芸術家の美術展や住 民の趣味を生かしたイベント等が開催されている。

以上より、各 CS は地域性を生かした多様で独自性の高い商品と サービスを提供している事が分かる。大型店との差別化による顧客 増加や満足度向上等に寄与寸る可能性が考えられる。

\section{3 利用建物の特徵}

利用建物は、旧商店の改修 5 件、納屋やパブ等の用途転用 3 件、 集会所の一部改修 2 件、新築 4 件であり、集落内の既存建物を活用 したものが多い。図 2 に利用建物の例を示す。旧商店や用途転用は、 既存建物の特徴や䨌囲気を残して改修している。集会所は、更衣室 やクローク等を商店として改修している。新築は、集落の雰囲気に 調和させながら、現代的な商店経営に適したデザインにしている。

建物所有者は、住民個人 4 件、CS 所有 3 件、集会所 3 件、集落 所有 2 件、トラスト 2 件である。そのうち 8 件の CS は、活動の価 值や公益性が評価され、無償または割引賃料で貸与している。

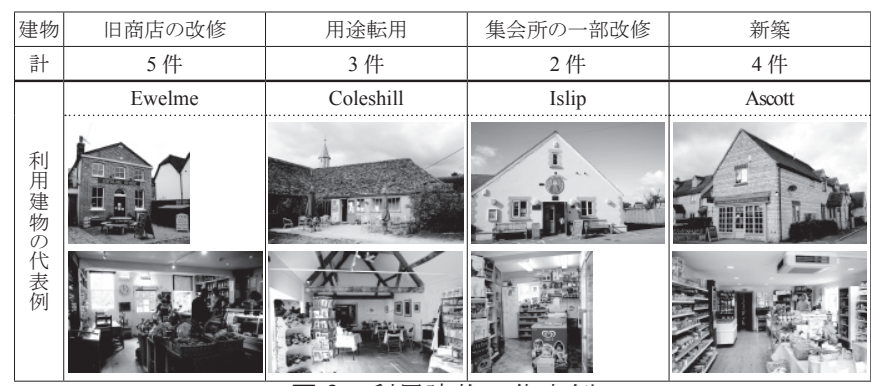

図 2 利用建物の代表例

表 1 コミュニティショップ活動の特徵

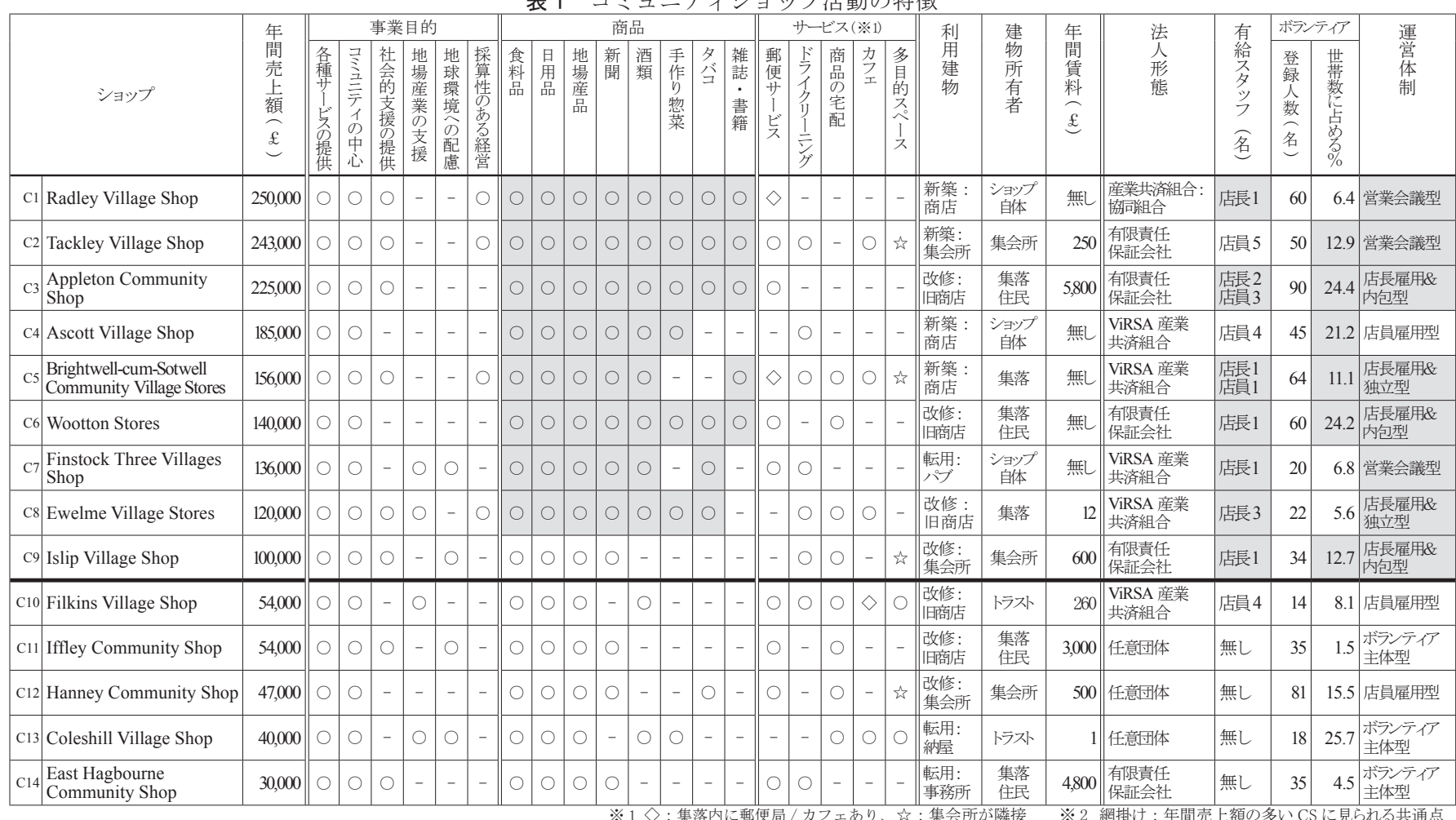




\section{4 法人形態清とスタッフの特徵}

法人形態は「ViRSA 産業共済組合」5 件、有限責任保証会社」4 件、 「任意団体」 3 件、「産業共済組合: 協同組合」 1 件の 4 種類見られる。

「ViRSA 産業共済組合」は、ViRSA が「産業共済組合: コミュニティ 利益」を、CS 専用に改訂した地域の公益を目的とする組合組織で ある。登録時間や費用削減等の利点があり多くのCS 使用する。「有 限責任保証会社」は助成金を申請できる上、株式資本もなく個人の 不利益を抑制できるためチャリティ等がよく使用する。「任意団体」 は法的規制のない非公式組織であり、登録や費用が必要なく自主規 制で運営する事ができる。一方、社会的信頼を得づらい側面もある。

スタッフを見ると、大部分の CS が有給スタッフを有する。7 件 では小売業経験のある店長を雇用して、日常業務の管理を一任して いる。しかし、ほとんどの有給スタッフは一般的な個人商店よりも 少ない賃金で働いている。また、全てのCS がロコミや地道な声か けでボランティアを集め、レジ打ちや商品陳列、掃除等を任せてい る。それらにより、人件費の削減に大きく貢献している。

\section{5 運営の難しい点と継続の秘訣の特徵（表 2)}

運営の難しい点は、「ボランティアの確保/管理」が 12 件と最も 多い。ボランティアは個人の自由意志であり、急用や長期休暇によ る欠勤も多く、シフト管理や人数確保が難しい。また、ボランティ アのやる気を高め、楽しみつつ責任を持って働けるように、全ての $\mathrm{CS}$ が年 1 - 2 回のパーティーを開いて日頃の労を㸚ぎらっている。

また、「仕入れ /在庫の管理」が 4 件、「良好な人間関係の構築」 が 3 件見られる。ニーズに合った商品を適切な数量仕入れて手頃な 価格で販売して利益を得るといらバランスを維持する事や、ボラン ティア同士や店長との寸れ違いを解消して CS 内の良好な人間関係 を構築する事の難しさを挙げている。

次に、継続の秘訣を見ると、「ニーズに対応する」「社会的支援の 充実」が 10 件ずつと最も多い。住民の声に耳を傾けて必要なサー ビスを提供する事や高龃者等への宅配や悩み相談等のサポートを拡 充する事の重要性を挙げている。また、「商品の質の向上」「心地よ い雾囲気／接客」も多く、新しい商品やアイデアを取り入れて CS の活気や新鮮味を保つ事や、顧客との積極的な会話や丁寧な振る舞

表 2 a）運営の難しい点、b）継続の秘訣（じちらも複数回答）

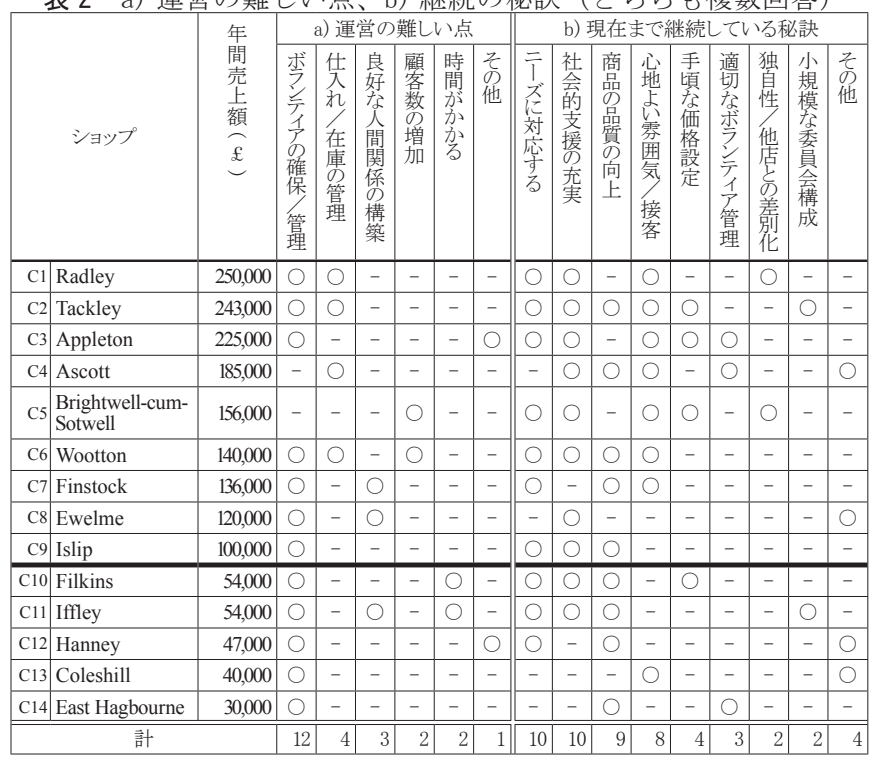

いで心地よい雾囲気をつくる事も挙げられている。

以上より、CS の運営では、(1)十分な数のボランティアを確保し高 いやる気を維持する事、(2)住民の声に耳を傾けて適切なサービスを 提供する事、(3)高齢者等へのサポートを拡充する事、(4)新しい商品 を取り入れて CS の活気を維持する事、(5)何度も訪れたくなる心地 よい雰囲気をつくる事に配慮する必要がある事が分かる。

\section{CS の採算性を支える要因の考察}

年間売上額は、 $£ 30,000$ から 250,000 と大きく開きがある。年間 売上額の多いCS に着目し、採算性を支える要因を考察する。

\section{1 商品の充実度（表 1 )}

商品を見ると、年間売上額の高い 8 件の CS は、6 種類以上の幅 広い商品を販売している。また、酒類やタバコ等の単価の高い商品 や各 CS 独自の手作り惣菜を販売している点が特徴といえる。

以上より、(1)様々な顧客ニーズに対応できるように幅広い商品展 開を行なう事、(2)単価の高い商品も扱う事、(3)各 CS 独自の商品を 販売する事が重要であると考えられる。

\section{2 専門性の高い人材の起用とボランティア率の高さ（表 1)}

有給スタッフを見ると、年間売上額の高い 7 件の CS は、店長を 雇用している。また、世帯数に対するボランティア率を見ると、年 間売上額の高いCS の方が、1 割以上の高い割合を有する傾向がある。

以上より、(1)小売業の専門知識と技術を持つ人材を起用する事、 (2) CS 活動に賛同し協力してくれる多くのボランティアを集落内で 獲得する事が重要であると考えられる。

\section{3 高度に組織化された運営体制}

まず、運営体制の特徵を示す。運営体制は、その組織化度涪によ り 5 つに分けられる（図 3)。「営業会議型」が最も組織化度が高く、 経営方針を検討する経営会議と日常業務を検討する営業会議の 2 部 門に分かれて運営する。営業会議では、営業内容や売上げ、課題等 の最新情報を共有し、日常業務を改善する為の具体的な方法が検討 される。「店長雇用型」は有給スタッフとして店長を雇用する。店 長の立場により「内包型」と「独立型」に分けられる。「内包型」 は経営委員会に店長も所属し、毎回の経営会議で経営方針と日常業 務双方の視点から運営方法が議論される。「独立型」では店長は経 営委員会から独立し、日常業務のより広範な権限を与えられて業務 全般を指揮する。「店員雇用型」は専門業務を実施するパートタイ ムの店員を雇用する。しかし、業務全般の指揮・管理は経営委員会 が実施する。「ボランティア主体型」は有給スタッフを雇用せず、 ボランティアのみで運営する。経営委員会が専門性の高い業務も担 当し、必要に応じて専門業務の補助をボランティアに依頼する。

次に、表 1 の年間売上額の多い CS に着目寸ると、その運営体制 は「営業会議型」「店長雇用\&内包型」「店長雇用\&独立型」の 3 つ となっている。とくに、営業会議型の 3 件中 2 件は、年間売上額が £240, 000 以上と非常に高額である。

以上より、運営体制の特徵として、(1)組織化度が高い場合、専門 業務について適切に役割分担や連携を行なう事で、日常業務の円滑 化やボランティアの負担軽減につながる事、(2)組織化度が低い場 合、ボランティアの負担が増加する一方、やりがいや満足感の醸成 につながる事が分かる。また、運営体制を高度に組織化する事で、 売上額の増加につながる可能性もあると考えられる。 


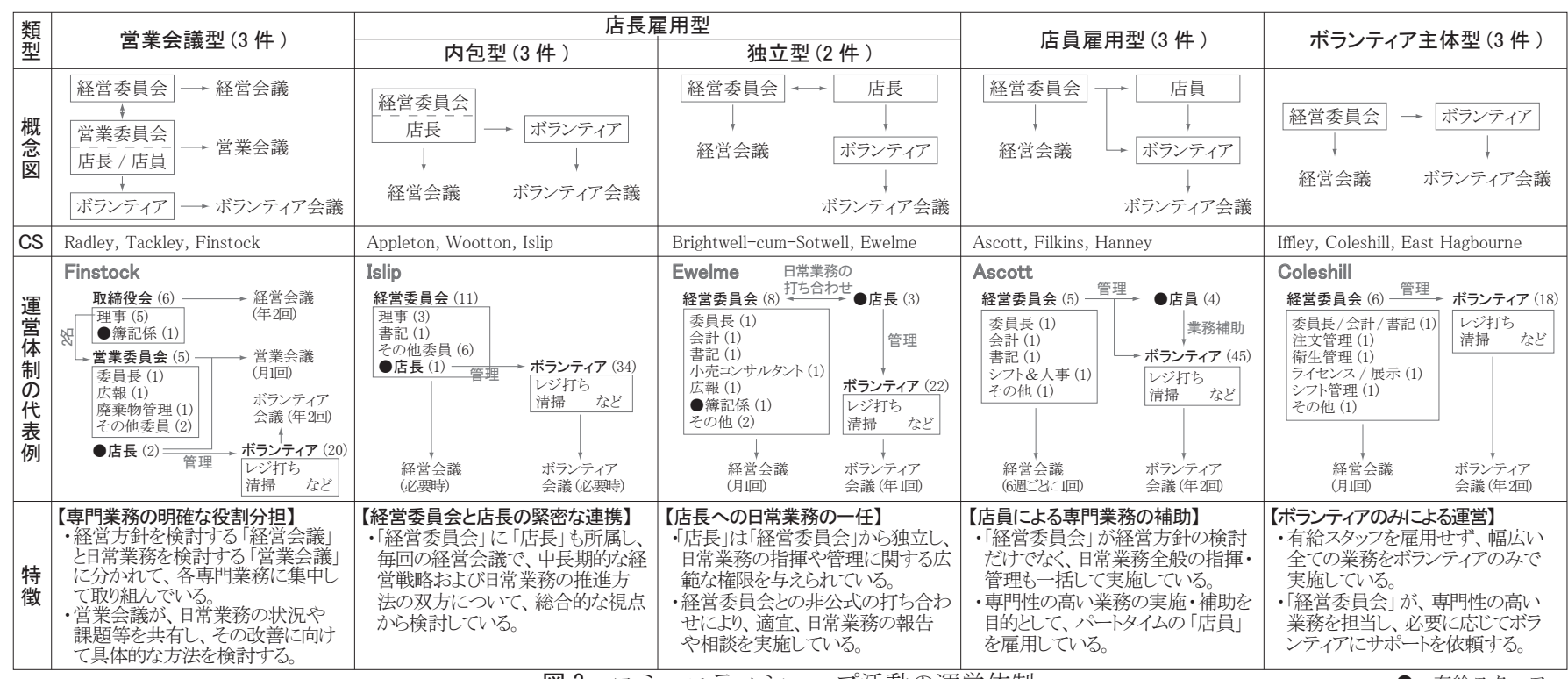

図 3 コミュニティショップ活動の運営体制 ○: 有給スタッフ

\section{4 コミュニティショップの活動実態}

年間売上額の多いCS の代表例として、「営業会議型:Finstock」「店 長雇用\&内包型 : Appleton」「店長雇用\&独立型 : Brightwe11-cumSotwe11」を取り上げ、CS の活動実態を示す。

(1)旧パブ倉庫を転用して地場産品の販売に力を入れる Finstock Three Villages Shop（図 4)

旧パブ倉庫を転用した Finstock は、野菜や加工肉、パン等の地場 産品や地元アーティスト制作のはがき等の販売に力を入れている。 また、当時の外観や建物構造を保全して、その特徴を生かした必要 最低限の改修を実施している。継続の秘訣は、人々のニーズへの対 応や訪問したくなるフレンドリーな場所づくりを挙げている。

(2)旧商店を改修して豊富な商品と高齢者等への見守りを実施する Appleton Community Shop（図 5)

旧商店を改修したAppleton は、近隣スーパーに負けない豊富な品 揃えや誰でも来ておしやべりしやすい場の提供、高齢者や障害者等 の見守りを実施している。また、旧商店の特徴を残しながらも、2 度の大規模な改装を実施して、清潔感のある明るい店内を作り出し ている。継続の秘訣は、ニーズに合った商品を手頃な価格で提供す る事や高齢者を始めとする人々を手助けする事を挙げている。

(3)新築で小さなカフェスペースを有する Brightwe11-cum-Sotwe11 Community Village Shop（図6）

新築したBrightwel1-cum-Sotwel1 は、小さなカフェスペースを設け、 人々の交流できる場を提供している。また、トップライトや手づく り店内装飾により、明るく温か夕のある雰囲気を演出している。継 続の秘訣は、スーパーとの差別化や競争力のある価格設定、フレン ドリーな場所づくりを挙げている。

\section{CS 準備段階の特徵と実現性を支える要因の考察（表 3)}

\section{1 発起人の分類}

CS はその発起人により「Parish Council注 (以下、PC)」と「集 落住民」に分類できる。さらに、「PC」はその実施内容により、PC が集落計画の策定を指揮した「集落計画の策定」2 件と集落会議で 住民に CS 開設を提案した「提案・呼びかけ」3 件に分けられる。ま

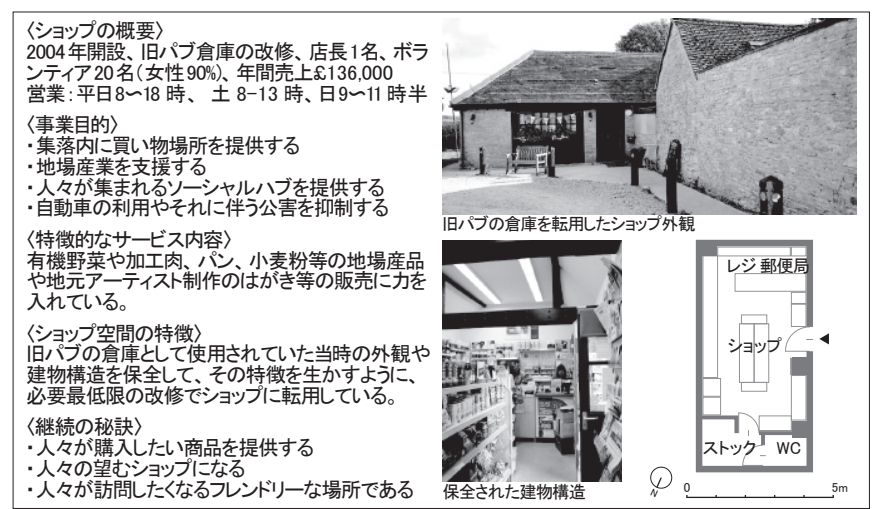

図 4 コミュニティショップの活動実態 (Finstock)

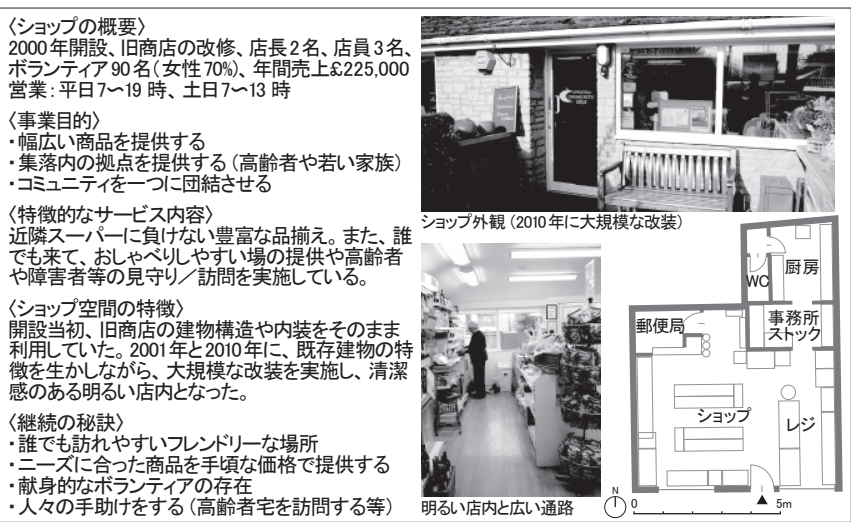

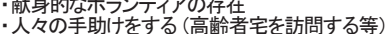

図 5 コミュニティショップの活動実態 (Appleton)

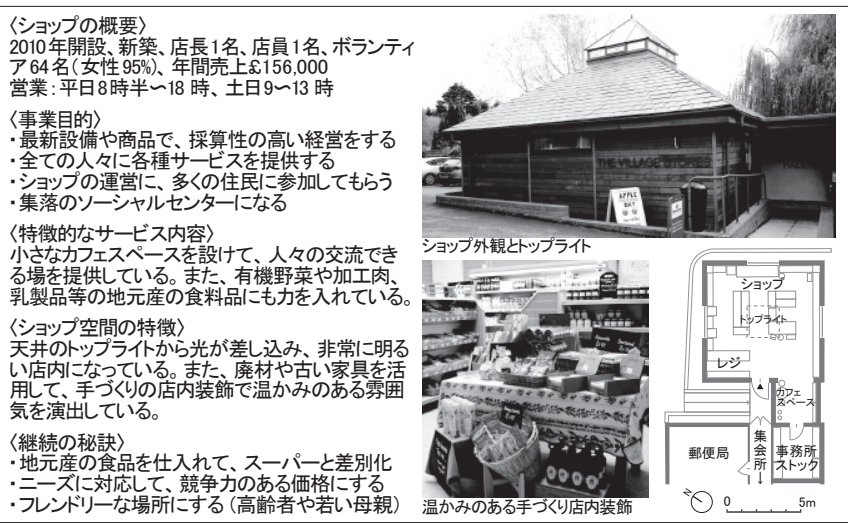

図 6 コミュニティショップの活動実態 (Brightwel1-cum-Sotwe11) 
た、「集落住民」はその特徴により、集落内の住民団体で活動して いた「市民活動の経験者」 3 件と一般住民の自主的な集まりである 「S 開設を望む一般住民」6 件に分けられる。

\section{2 開設資金の調達方法}

開設資金は£3,000 から£400,000 と大きく開きがあり、高額な開 設資金なほど、準備期間が長い傾向がある。また、利用建物との 関係性が大きく、建物の新築や大規模な改修を実施した 7 件は、 $£ 60,000$ 以上の高額な開設資金を必要とした。

資金調達方法を見ると、12 件の CS が住民から寄付やローンを獲 得しており、うち8 件では資金総額の 2 割以上を占める主要な資金 調達先の一つになっている。高額な開設資金を必要としたCS では、

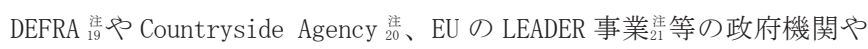
Plunkett から助成金を獲得している。また、PC や ORCC は多くの CS に小額の助成金を提供している。さらに、CS 準備委員会自身がガ レージセールやパーティー等の資金調達イベントも実施している。

\section{3 開設のきっかけ}

きっかけを見ると、「旧商店の閉店」 14 件、「郵便局の閉鎖」 7 件 と多く見られ、日常的な生活機能の喪失が主な要因となっている。

表 3 コミュニティショップ準備段階の特徵

\begin{tabular}{|c|c|c|c|c|c|c|c|c|c|c|c|c|c|c|c|c|c|c|c|c|c|}
\hline \multirow{2}{*}{\multicolumn{2}{|c|}{$\begin{array}{l}\text { 永 } \\
\text { 起 } \\
\text { 只 } \\
\text { 頒 }\end{array}$}} & \multirow{2}{*}{\multicolumn{2}{|c|}{ ショップ }} & \multirow{2}{*}{$\begin{array}{l}\text { 閉 } \\
\text { 年 }\end{array}$} & \multirow{2}{*}{$\begin{array}{l}\text { 隻 } \\
\text { 備 } \\
\text { 簡 }\end{array}$} & \multirow[b]{2}{*}{$\begin{array}{l}\text { 閠 } \\
\text { 凟 } \\
\text { 金 } \\
\text { £ }\end{array}$} & \multicolumn{6}{|c|}{ 資金調達方法 (※1) } & & \multicolumn{2}{|c|}{ きっかけ } & \multicolumn{6}{|c|}{ 開設までの難しい点 } \\
\hline & & & & & & & 政 & 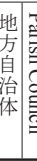 & & & 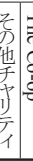 & & & 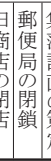 & 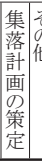 & & 齐 & & & & $\begin{array}{l}\vdots \\
\bar{c} \\
\text { 他 }\end{array}$ \\
\hline \multirow{5}{*}{. } & \multirow{2}{*}{$\begin{array}{l}\text { 許集洛 } \\
\text { 棌 }\end{array}$} & & Ewelme & 2009 & 2年半 & 75,000 & 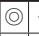 & - & & (2) & - & & 0 & $5-$ & 0. & & 0 & 1 & - & 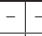 & 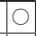 \\
\hline & & & Filkins & 2005 & 1年 & 20,000 & (2) & $-1 \mathrm{c}$ & . & - & 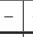 & 0 & (6) & $5-$ & 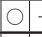 & & - & $-\mathrm{C}$ & & 0 & - \\
\hline & \multirow{3}{*}{ 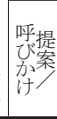 } & $\mathrm{Cl}$ & Appleton & 2000 & 1ヶ月半 & 6,000 & 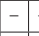 & $-\mathrm{C}$ & c & & - & (c) & $-c^{-1}$ & $5-$ & - & & 0 & & 0 & - & 0 \\
\hline & & & $\begin{array}{l}\text { Brightwell- } \\
\text { cum-Sotwell }\end{array}$ & 2010 & 8 年 & || 225,000 & 0 & 0 & o & & 0 & c & & 0 & 0 & c & - & D & & & 0 \\
\hline & & $\mathrm{Cl} 2$ & Radley & 2007 & 1年 & 60,000 & - & $-1-$ & - & (2) & - & (2) & & 2- - & -18 & & - & - & - & - & - \\
\hline & \multirow{3}{*}{ 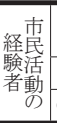 } & & $\begin{array}{l}\text { East } \\
\text { Hagbourne }\end{array}$ & 2001 & 1 年 & 3,000 & & 0 & (o & & & - & & 0 & & & 0 & & & & 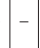 \\
\hline & & & Hanney & 1986 & 1 年 & 5,000 & & (a) & c c & & - & - & 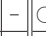 & - & - & & 0 & & & $\mathrm{O}$ & - \\
\hline & & C10 & Iffley & 1999 & 6ケ月 & 8,300 & & o- - & - & & (?) & & 0 & $\mathrm{DO}$ & $-1 \mathrm{c}$ & & of & $D$ & 0 & - & - \\
\hline & \multirow{6}{*}{ 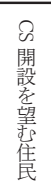 } & C2 & Ascott & 2003 & 1年 & 80,000 & () & $-c$ & - & & & 0 & & $0-$ & -8 & & - & & & & - \\
\hline & & & Coleshi & 2004 & 2 年 & 6,000 & & $-1 C$ & (c) & & - & (2) & (2) & 0 & -7 & & - & - & - & - & C \\
\hline & & & Finstock & 2004 & 4年 & 105,000 & (2) & $-c$ & & C & -16 & $\mathrm{O}$ & & 00 & -8 & & $-1 \mathrm{c}$ r & & & & o \\
\hline & & & Islip & 2000 & 6ケ月 & 7,500 & 0 & & c & & & (c) & & D- & $-7 c$ & & 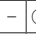 & & & & - \\
\hline & & & Tackley & 2004 & 5 年 & 400,000 & (2) & & c & & & & & 50 & $-1 \mathrm{c}$ & & -5 & & & - & o \\
\hline & & & Wootton & 2007 & 6ケ月 & 74,000 & & & & & & & & 同 & - & & - & & & & \\
\hline
\end{tabular}

一方、「その他」6 件には、Local Agenda21 グルーフプ 弟が他地域でCS を実施、集会所の増築による空室の発生等が見ら れる。生活機能の喪失と共に、発起人の活動や人間関係、集落内の 前向きな状況変化が CS 開設を後押しする要因となっている。

\section{4 開設までの難しい点}

開設の難しい点は、「資金調達」が 8 件と最も多い。とくに、高 額な開設資金を必要としたCS ゙゙多く見られ、助成金の申請やイ心゙ ントの実施等に膨大な手間と時間を強いられた事を挙げている。

また、「ボランティアの確保」「建物／敷地の獲得」も多く見られ、 とくに、「集落住民」が発起人の場合に多く、集落内で十分な信頼 を獲得して活動に協力してくれる人材を集める事や適切な場所を探 してオーナーと交渉する事の苦労を挙げている。その他に、多くの 準備委員会メンバーが働いており、まとまった準備時間を作りづら い事や郵便局スタッフとの交渉が難航した事なども見られる。

\section{5 発起人の分類からみた開設プロセスの特徵（図 7)}

開設プロセスを見ると、まず全体の共通点として、全ての CS が 集落全体を対象にニーズ調查を実施して、大部分の住民から賛同や 協力希望を獲得している事が挙げられる。集落全体の合意の基で、 具体的な準備作業を開始している。

次に、発起人別の開設プロセスを見ると、準備委員 会発足までの「初動期」に特徵が見られるため、「初 動期」に着目して代表例を考察する。「準備期」では 資金調達や建物探し、しつらえ等が共通するが、各集 落の状況により多様なプロセスを経ている。

「PC：集落計画の策定」のFilkins では、PC が集落 計画の策定に向けて行動を開始した。PC 指揮の下、 住民による集落計画委員会が発足し、集落全体の要望 や意見を把握するために全世帯アンケートを実施し た。その結果、市民農園や児童公園等の設置と共に、 CS 開設を望む声が多く、当時の PCメンバーであった 小売業経験者を中心にCS 準備委員会を発足した。次 に、「PC : 提案・呼びかけ」のAppleton では、旧店主 から引退連絡を受けた PC が、その後の選択肢を検討 する為に PC 内でビジネスグループを設立して活動を

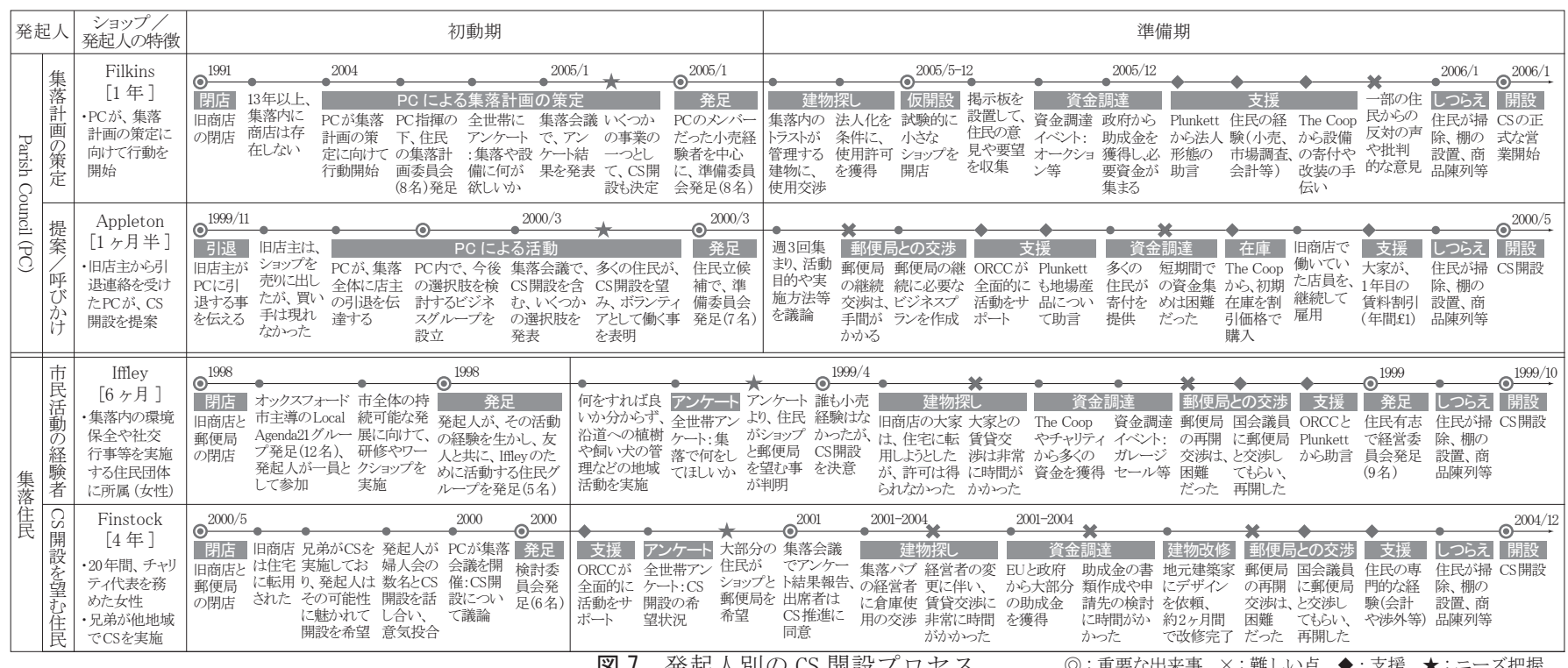


表 4 各支援主体による CS 開設までの支援内容

※[]内は、その支援を受けた CS 件数

\begin{tabular}{|c|c|c|c|c|c|c|c|c|}
\hline \\
\hline & 政府 & 地方自治体 & Parish Council (PC) & ORCC & ViRSA / Plunkett & その他チャリティ & The Coop & 住民 \\
\hline $\begin{array}{l}\text { 財 } \\
\text { 晸 } \\
\text { 援 }\end{array}$ & $\begin{array}{l}\text { • 助成金の提供 [6 件] } \\
\text { (LEADER Program 等) }\end{array}$ & $\begin{array}{l}\text { - 助成金の提供 [6 件 ] } \\
\text { - 営業税の割引 [1 件 ] }\end{array}$ & $\begin{array}{l}\text { •小額の助成金の提供 } \\
\text { [10 件 }\end{array}$ & $\mid$\begin{tabular}{|l} 
·小額の助成金の提供 \\
[11件
\end{tabular} & \begin{tabular}{|l|}
$\cdot$ Village CORE Program \\
等の助成金とローンの \\
提供 7 件 $]$
\end{tabular} & 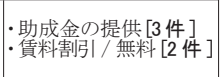 & $\mid \begin{array}{l}\text { - 助成金の提供 [5 件 ] } \\
\text { - } \text { 口-ンの提供 } 11 \text { 件 }]\end{array}$ & 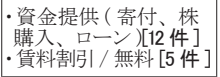 \\
\hline 辣 & - & $\begin{array}{l}\cdot \cdot \text { 計画許可による建物 } \\
\text { 用途規制 [2 件] } \\
\cdot \text { 情報提供 (法律 } \\
\text { 助成金など)[10 件 ] }\end{array}$ & $\begin{array}{l}\text { ·集落会議主催 [3 定件 }] \\
\text { ·指揮 } \\
{[2 \text { 件 }]}\end{array}$ & 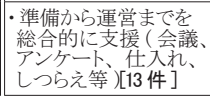 & $\begin{array}{l}\text {-CSに関する総合的なアド } \\
\text { ハイ (特人形態 } \\
\text { について }[10 \text { 件 }]\end{array}$ & - 建物の改修 [1件 ] & \begin{tabular}{|l|} 
• 小売業や商品に関す \\
る専門アドバイス 2 件 $]$
\end{tabular} & \begin{tabular}{|c} 
- 専門知識の舞償提供 \\
建築管、理等) [3 件]
\end{tabular} \\
\hline 食 & - 郵便局との交渉 [3 件 ] & - & - & - & - & - & |-しつらえ作業 [1件 ] & \begin{tabular}{|l|l|}
$\cdot$ 七つらえ作業 [14 件 $]$ \\
$\cdot$ 地元大工業 \\
{$[1$ 件 $]$}
\end{tabular} \\
\hline
\end{tabular}

始めた。集落会議でCS 開設を含む数種類の選択肢を発表した際、 多くの住民が CS 開設を望み、ボランティアで働く事を表明したた め、住民の立候補で CS 準備委員会を発足した。

以上より、PC が発起人の場合、住民による CS 準備委員会を発足 する前に、PC が集落全体のニーズ調査や合意形成等の下準備を実 施している事が分かる。そして、その下準備により、CS 開設に向 けて住民が行動しや寸い土㙵の形成やCS 準備委員会の作業負担の 軽減につながっていると考えられる。

「市民活動の経験者」の Iffley では、集落に長年居住し、集落内 の環境保全等を経験した女性が、0xford 市主催の Local Agenda 21 グループに参加し刺激を受けて活動を開始した。友人らと集落活性 化に向けた住民グループを発足し、全世帯ニーズ調査を実施した。 その結果、商店の再開を望む声が多かったためCS 開設を決意した。 「CS 開設を望む一般住民」では、商店の再生・継続を願う様々な住 民が集まっており、そのプロセスは様々である。例えば Finstock では、長年チャリティ団体の代表を務めた女性が、CS を実施する 兄弟から CS の持つ可能性を聞き、開設に向けて行動を開始した。 PC や集落内の住民団体に話を持ちかけて CS 検討委員会を発足した。

以上より、集落住民が発起人の場合、集落環境の維持や CS 開設 に対する熱意が原動力である事が分かる。また、市民活動の経験者 は、活動経験や集落内外の人脈を生かして準備する事も分かる。

\section{6 CS 開設までの支援内容の特徵（表 4)}

支援内容は 4 つに分けられる。財政支援では、全ての支援主体が 助成金や寄付等を提供しており、とくに、政府と Plunkett が£10, 000 以上の高額な助成金を提供する財政支援の中心となっている。ま た、技術支援でも大部分の支援主体が情報提供や専門アドバイスを 実施している。とくに、ORCC と Plunkett は、大部分の CS に開設 までの総合的な支援やアドバイスを実施しており、CS 開設の重要 な中間支援組織となっている。さらに、支援内容や効果の充実を図 る為に、CS 支援に関する協力体制を構築して定期的な打合せや情 報交換も実施している。人的支援では、住民による棚の設置や壁の 塗装等のしつらえ作業が中心である。物的支援では、The Coop や 住民等による設備等の寄付や建物の無償提供がわずかに見られる。

以上より、CS 開設の実現性を高める為に、(1) CS 活動や集落再生 に関する専門的な知識や技術を有する ORCC や Plunkett のような中 間支援組織による総合的な開設支援、(2)中間支援組織の密接な協力 体制の構築による支援内容の拡充が重要であると考えられる。

\section{7 まとめ}

\section{1 調査結果の整理}

本研究で得られた調查結果は以下の通りである。
1）コミュニティショップ活動の特徴

(1) CS 活動は、その継続性の高さが評価され住民主体による集落再 生の成功事例として位置付けられている。(2)事業目的は、サービス の提供だけでなく、交流拠点、福祉拠点、産業支援、環境共生とい う公益性の高い多様なテーマを掲げている。(3)各集落の地域性を生 かした多様で独自性の高い商品とサービスを提供している。(4)集落 内の既存建物を活用した CS が多く、当時の雾囲気を残した改修を 実施している。(5) CS 活動の価值が評価され、建物を無償や割引貸 料で貸与している。(6)運営の難しい点は、十分な数のボランティア を確保し、やる気を維持する事である。77継続性の秘訣は、住民の 声に耳を傾ける事や高齢者等への社会的支援を充実する事である。

2) コミュニティショップの採算性を支える要因

(8)様々な顧客ニーズに対応できるように幅広い商品展開を行なう。 (9)各 CS 独自の商品を販売する。(10)小売業の専門知識と技術を持つ 人材を起用して日常業務の推進を一任する。(11) CS 活動に賛同し協 力してくれるボランティアをなるべく多く集める。12高度に組織化 した運営体制により、専門業務の役割分担や連携を行なう。

3）コミュニティショップ開設の実現性を支える要因 (13)住民が開設準備を始めやすい土壌の形成や作業負担の軽減の為 に、PC が集落全体のニーズ調查や合意形成等の下準備を実施する。 (14) ORCC や Plunkett のような、CS 活動や集落再生に関する専門知識 と技術を有する中間支援組織による総合的な開設支援を提供する。 (15)それら中間支援組織同士の密接な協力体制を構築して、支援内容 や効果の拡充を図る。

\section{2 住民主体で集落生活機能を維持する際の留意点}

英国と我が国の集落では、人口規模や高齢化率、ボランティア文 化の定着度など様々な相違点がある。英国の事例をそのまま我が国 に転用する事は難しいが、住民主体で集落生活機能を維持する際の 留意点として、以上の結論から得られた知見を以下に示寸。

1）住民主体による生活機能の再生の実現性を高める為に、各分野 の専門知識と技術を有する中間支援組織が、準備から運営までの総 合的な支援を実施する必要がある。2）また、一つの組織が全ての 支援を提供する事は困難であり、異なる専門分野を有する中間支援 組織同士や行政、チャリティ団体等との協力体制を構築して支援内 容を拡充する事が重要である。3）さらに、PCのような住民に最も 近い地縁自治組織が、準備段階でニーズ調查や合意形成等の手助け をする事も重要である。4）住民主体による生活機能運営の採算性 を高める為にも、集落内の様々な住民ニーズを把握して適切に対応 する必要がある。5）また、関連分野の専門知識と技術を持つ人材 を起用して日常業務の管理を一任する事も重要である。6）運営体 制を高度に組織化し専門業務の分担や連携を図る事も重要である。 


\section{謝辞}

本研究を進めるに当たり、John Stead 夫妻をはじめ、Tom Morris 氏やKate Forrest 氏、各 CS の代表者など多くの方々にご協力をい ただいた。末尾ではあるが、ここに感謝の意を表したい。

注

注 1) Plunkett Community Shop Network : http://www. plunkett.uk. net/ (最終確認：2011 年 9 月)

注 2) 表 5 にCounty 別の CS 件数上位 10 件を示寸

表 5 County 別の CS 件数 (上位 10 件、2011 年 9 月現在)

\begin{tabular}{|c|c|c|c|c|c|c|c|c|c|c|c|}
\hline Countv & 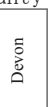 & 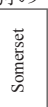 & 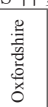 & 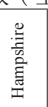 & 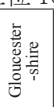 & 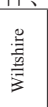 & $\begin{array}{l}\text { 总 } \\
\text { 悹 }\end{array}$ & $\begin{array}{l}\text { 总 } \\
\text { 密 }\end{array}$ & 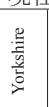 & 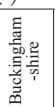 & 計 \\
\hline South West & 23 & 18 & & & 14 & 13 & & & & & 68 \\
\hline \begin{tabular}{|l|} 
South East \\
\end{tabular} & & & 18 & 14 & & & 11 & & & 8 & 51 \\
\hline East of England & & & & & & & & 11 & & & 11 \\
\hline $\begin{array}{l}\text { Yorkshire and the } \\
\text { Humber }\end{array}$ & & & & & & & & & 9 & & 9 \\
\hline 計 & 23 & 18 & 18 & 14 & 14 & 13 & 11 & 11 & 9 & 8 & 139 \\
\hline
\end{tabular}

注 3) 表 6 に上位 3 件の CS 累計件数を示す。また、英国全体で 8 件の CS が閉鎖したが、下記 3 件のCounty の CS は含まれていない。 表 6 上位 3 件の CS 累計件数（2011 年 9 月現在）

\begin{tabular}{|l|r|r|r|r|r|r|r|r|r|r|r|r|}
\hline \multirow{2}{*}{ County } & \multicolumn{10}{|c|}{ 西暦年 } \\
\cline { 2 - 21 } & -2000 & 2001 & 2002 & 2003 & 2004 & 2005 & 2006 & 2007 & 2008 & 2009 & 2010 & 2011 \\
\hline Oxfordshire & 5 & 7 & 7 & 9 & 12 & 13 & 13 & 15 & 15 & 17 & 18 & 18 \\
\hline Devon & 1 & 3 & 4 & 5 & 7 & 8 & 11 & 12 & 13 & 20 & 22 & 23 \\
\hline Somerset & 6 & 7 & 9 & 9 & 9 & 9 & 11 & 12 & 13 & 16 & 17 & 18 \\
\hline
\end{tabular}

注 4) Plunkett Foundation は、1919 年に集落内の課題を管理するために、 住民の共同所有という概念を通して、集落コミュニティを支援する事を 目的に設立した全国的な組織である。CS の支援を始め、その他社会的企 業や地場の食料品に対する支援を実施する。

注 5）ORCC は、1920 年に地元の集落生活に関心がある人々を団結させる 為に設立したチャリティ組織である。CS 開設や集落計画の策定、公共交 通の充実、手頃な価格の住宅供給など様々な支援を展開する。

注 6）現地で収集した文献を、参考文献 17）－22）に示す。

注 7）表 7 に対象集落の概要を示す。

表 7 対象集落の概要

\begin{tabular}{|c|c|c|c|c|c|c|c|c|c|c|c|c|c|c|c|}
\hline ショップ & 数 & 思性 & 数 & 带 & 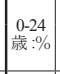 & 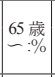 & 㹃呀 & 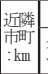 & 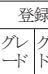 & & 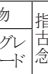 & & & 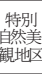 & 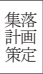 \\
\hline Radley & 2774 & 1696 & 1078 & 932 & 40.5 & 14.4 & 36.9 & \begin{tabular}{ll|}
3.4 \\
\end{tabular} & 0 & 4 & 26 & & & - & 2011 \\
\hline \begin{tabular}{|l|l|} 
C2 & Tackley \\
\end{tabular} & 8 & 478 & 480 & 387 & 27.4 & 16.5 & 40.5 & \begin{tabular}{|l|l|}
4.6 \\
\end{tabular} & & & 35 & & 35.4 & & \\
\hline \begin{tabular}{|l|l|} 
C3 & Appleton \\
\end{tabular} & 7 & 464 & 433 & 369 & 27.4 & $\mid 16.5$ & 40.8 & 7.1 & & & 34 & & 11.8 & & 2010 \\
\hline \begin{tabular}{|l|l|l|} 
C4 & Ascott \\
\end{tabular} & 04 & 242 & \begin{tabular}{l|l}
262 \\
\end{tabular} & 212 & 25.6 & $|16.7|$ & 41.7 & 10.1 & 0 & 2 & 21 & & - & 全体 & \\
\hline \begin{tabular}{|l|l|l|} 
C5 & Brightwell-cum- \\
Sotwell
\end{tabular} & 1530 & 723 & 807 & 574 & 25.6 & 22.3 & 43.9 & 3.2 & 1 & 3 & 46 & & 37. & 一部 & $\begin{array}{l}2004 \\
2006\end{array}$ \\
\hline \begin{tabular}{|l|l|l|} 
C6 & Woot \\
\end{tabular} & & 257 & 286 & 248 & 22.7 & \begin{tabular}{|l|}
18.6 \\
\end{tabular} & 43.0 & 3.2 & 0 & & 34 & & 201.2 & & \\
\hline \begin{tabular}{|l|l|} 
C7 & Finstoc \\
\end{tabular} & 77 & 364 & 343 & 292 & 27.0 & \begin{tabular}{|l|}
14.9 \\
\end{tabular} & 40.7 & \begin{tabular}{|l|}
3.0 \\
\end{tabular} & 0 & & 24 & & 117.7 & 一部 & \\
\hline C8 Ewe & 3 & 559 & 544 & 393 & 34.1 & 9.7 & 33.1 & \begin{tabular}{|l|l|}
4.2 \\
\end{tabular} & 4 & & 42 & & 29.1 & 全体 & 200 \\
\hline C9 Islip & 617 & 306 & 311 & 267 & 24.2 & \begin{tabular}{|l|}
17.5 \\
\end{tabular} & 42.0 & 3.6 & & & 23 & & 29.5 & & \\
\hline C10 Filkins & 04 & $201 \mid$ & 203 & 172 & 24.8 & \begin{tabular}{|l|}
17.6 \\
\end{tabular} & 42.3 & 8.3 & 0 & & 46 & & 46.9 & & 200 \\
\hline fflle & & 2939 & 3086 & 2388 & 34.1 & 16.4 & 37.7 & 2.8 & 0 & & & & 25.9 & & \\
\hline Han & 1242 & 611 & 631 & 521 & 23.9 & 17.6 & 43.4 & 2. & 0 & & 50 & & 23.1 & - & 2 \\
\hline $\mathrm{C}$ & 163 & 82 & 81 & 10 & 2 & & & 5. & 0 & & 41 & & 15. & 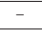 & \\
\hline \begin{tabular}{|l|l|} 
C14 & East Hagbour
\end{tabular} & 1881 & 9666 & \begin{tabular}{|l|l|}
915 \\
\end{tabular} & 773 & 30.8 & \begin{tabular}{|l|}
13.4 \\
\end{tabular} & & 1. & & & 41 & & 24.0 & - & 201 \\
\hline
\end{tabular}

注 8) 登録建造物 (Listed Building) 制度は、登録建物の特徴を保つために 日常的な維持管理を義務づける。改修や修繥等、建物の特徴に影響を及ぼ 寸場合は、「計画許可 (Planning Permission)」と「登録建造物同意書 (Listed Building Consent)」を地方自治体に提出して、許可を得る必要がある。

注 9）保全地区（Conservation Area）は、地域内の歷史的な建造物群や自然 環境の価值を評価して指定される。規制は1 新築や増築の際、周辺環境に 調和したデザインや形態、素材にする(2)伝統的な素材や技術を用いて歴史 的な建物の価值を高める(3)定期的に樹木や垣根を手入れする等である。

注 10）特別自然美観地区の規制は、通常の開発許可制度によって行なわれ、 地方自治体による審査時に、自然環境と調和しているかどうか審査される。

注 11） 2001 年から、住民が集落の課題解決に向けた集落計画 (Parish Plan) を策定・実践する「The Parish Action Plan Process」が始まり、全国約 10,000 件の Parish 中、約 3,000 件の Parish が約 1, 300 件の集落計画を策 定している (複数の Parish で共同作成が可能)。0xfordshireでは、2011 年 6 月現在、全 299 件のParish のうち、57 件が実践中、 66 件が策定中である。 注 12）表 8 に対象集落内の生活機能を示す。

注 13）参考文献 14）－17）を参照。

注 14）現在も、明確にCS の定義が決まっている訳ではないが、CS 運営者 や支援組織の間では、「コミュニティのために、コミュニティ自身によっ て計画・運営される商店」という共通認識が存在している。

注 15）図 8 に英国におけるCS 開設件数の推移を示す。
表 8 対象集落内の生活機能

\begin{tabular}{|c|c|c|c|c|c|c|c|c|c|c|c|c|}
\hline ショップ & 宗教 & $\begin{array}{l}\text { ス゚゚ー゙ } \\
\text { グラウド }\end{array}$ & 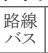 & 监童 & $\begin{array}{l}\text { 小学 } \\
\text { 椄 }\end{array}$ & \begin{tabular}{|l|} 
集会 \\
列
\end{tabular} & \begin{tabular}{|l|} 
スポーヅ \\
ヘヒヒリオン
\end{tabular} & パフ & \begin{tabular}{|l|l} 
鉄道 \\
駅
\end{tabular} & \begin{tabular}{|l|} 
飲食 \\
店
\end{tabular} & 医療 & \begin{tabular}{|l|} 
図書 \\
館
\end{tabular} \\
\hline \begin{tabular}{l|l}
$\mathrm{Cl}$ & Appleton \\
\end{tabular} & 0 & 0 & 0 & - & 0 & 0 & 0 & 0 & - & - & - & - \\
\hline \begin{tabular}{l|l}
$\mathrm{C} 2$ & Ascott \\
\end{tabular} & 0 & $\mathrm{O}$ & 0 & 0 & 0 & 0 & 0 & - & 0 & - & - & - \\
\hline $\begin{array}{ll}\text { C3 } & \text { Brightwell-cum-Sotwell }\end{array}$ & 0 & 0 & 0 & 0 & 0 & 0 & 0 & 0 & - & - & - & - \\
\hline \begin{tabular}{l|l}
$\mathrm{C} 4$ & Coleshill \\
\end{tabular} & 0 & 0 & 0 & 0 & 0 & - & 0 & 0 & - & - & - & - \\
\hline \begin{tabular}{l|l} 
C5 & East Hagbourne \\
\end{tabular} & 0 & 0 & 0 & 0 & 0 & 0 & 0 & - & - & - & - & - \\
\hline \begin{tabular}{l|l|l} 
C6 & Ewelme \\
\end{tabular} & 0 & 0 & 0 & 0 & 0 & 0 & 0 & 0 & - & - & - & - \\
\hline $\begin{array}{ll}\text { C7 } 7 \text { Filkins } \\
\end{array}$ & 0 & 0 & 0 & 0 & - & 0 & - & 0 & - & 0 & - & - \\
\hline \begin{tabular}{ll|l} 
C8 & Finstock \\
\end{tabular} & 0 & 0 & 0 & 0 & 0 & 0 & 0 & 0 & 0 & - & - & - \\
\hline $\begin{array}{ll}\text { C9 } & \text { Hanney } \\
\end{array}$ & 0 & 0 & 0 & 0 & 0 & 0 & 0 & 0 & - & 0 & - & - \\
\hline C10 Iffley & 0 & 0 & 0 & 0 & 0 & 0 & 0 & 0 & - & 0 & - & - \\
\hline \begin{tabular}{ll|l} 
C11 Islip \\
\end{tabular} & 0 & 0 & 0 & 0 & 0 & 0 & 0 & 0 & 0 & - & - & - \\
\hline $\begin{array}{ll}\text { C12 } & \text { Radley } \\
\end{array}$ & 0 & 0 & 0 & 0 & 0 & 0 & 0 & 0 & 0 & - & - & - \\
\hline \begin{tabular}{l|l} 
C13 & Tackley
\end{tabular} & 0 & 0 & 0 & 0 & 0 & 0 & 0 & 0 & 0 & - & - & - \\
\hline \begin{tabular}{l|l|} 
C14 & Wootton \\
\end{tabular} & 0 & 0 & 0 & 0 & 0 & 0 & 0 & 0 & - & - & - & - \\
\hline 計 & 14 & 14 & 14 & 13 & \begin{tabular}{l|l|}
13 \\
\end{tabular} & 13 & 13 & 12 & $\frac{25}{2}$ & 3 & 0 & \\
\hline
\end{tabular}

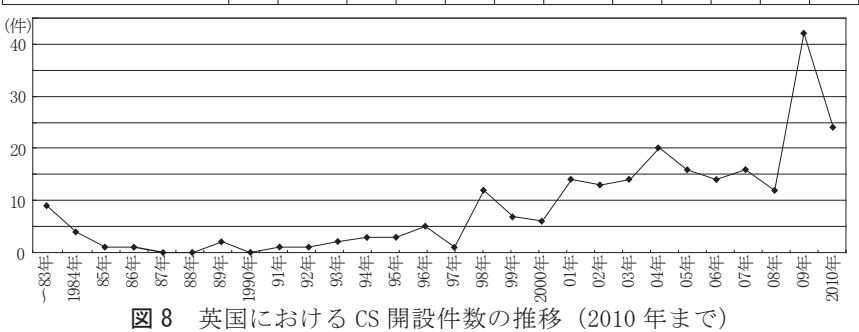

図 8 英国における CS 開設件数の推移（2010 年まで）

\begin{tabular}{|c|c|}
\hline 法人形態 & 楖要 \\
\hline $\begin{array}{l}\text { 有限責任保証会社 } \\
\text { (Company limited by guarantee) }\end{array}$ & 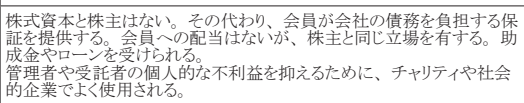 \\
\hline $\begin{array}{l}\text { ViRSA 产業共済組合 } \\
\text { (ViRSA Industrial and Provident Society [IPS] } \\
\text { model rules) }\end{array}$ & 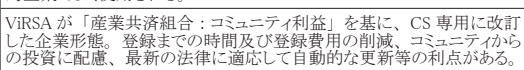 \\
\hline $\begin{array}{l}\text { 彦業共済組合 : コミュニティ利益 } \\
\text { (IS - for the befit of the community) }\end{array}$ & 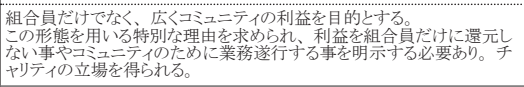 \\
\hline $\begin{array}{l}\text { 産業共済組合：協同組合 } \\
\text { (IPS - co-operative) }\end{array}$ & 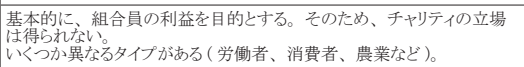 \\
\hline $\begin{array}{l}\text { 任意団体 } \\
\text { (Community Group) }\end{array}$ & 堛できる的制を伴わない、インフォーマルな団体であり、自己規制により運 \\
\hline
\end{tabular}

注 16）表 9 に法人形態の概要を示す。

注 17) 組織化度は、CS 運営体制について、(1)専門部門の設置状況と (2)専 門技術を持った人材の配置状況により分類している。組織化度の高いCS は、業務が役割分担されており、専門知識を持つ店長や店員を起用して いるものを指している。

注 18） PC は、英国の地方自治体の階層性において最も小さな自治体機 能であり、日本の県機能に相当する「County」、市町機能に相当する 「District」の下に位置づけられている。

注 19）環境食料農林省 (Department for Environment, Food and Rural Affairs) の略称であり、全国的に様々な助成金を提供する。

注 20）Countryside Agency は、1999 年に集落環境や住民生活の質を向上す るために設立された法定組織である。Defra から、毎年 100 万ポンドの予 算を得た。2006 年、いくつかの組織と合併し、Natural Englandになった。 注 21）LEADER 事業は、1991 年から 2008 年まで 3 期に分けて実施された EU の農村開発政策であり、条件不利農村地域で、住民参加型の地域再生を 実施する為に、行政、民間、住民等のパートナーシップを推進する。

注 22） 1992 年にリオ・デ・ジャネイロの地球サミットでの Agenda 21 の 採択を受けて、1997 年にブレア首相は全ての自治体でLocal Agenda 21 を策定する事を義務づけた。その策定は、市民が主体となり策定したも のが多く、0xford では 1 名の市職員と 12 名の有志市民で策定された。

\section{参考文献}

1）唐崎卓也，木下勇：農村地域の共同店にみられる地域協働に関する研究， 日本建築学会計画系論文集, 76, 664, pp. 1121-1128, 2011.6

2）草野拓司, 澤野久美, 田畑保：農村版コミュニティ・ビジネスの展開に 関する実証的分析, 明治大学農学部研究報告, 59(3), pp. 53-60, 2010.2

3）柳澤友樹, 高山純一，中山晶一朗：過疎地域における行政主導型の住民 参加実施によるコミュニティバス運行計画策定とその効果分析，土木計画 学研究・論文集, 22, pp. 921-931，2005.10

4) 川端光昭, 松本昌二, 佐野可寸志, 土屋哲 : 地方集落におけるバス運営の自律 型移行に対する受容意識と方略, 社会技術研究論文集 , 7, pp. 162-170, 2010.3

5）山下良平, 一八瀬友博：地域発展過程の合意形成の特性に着目し た過疎地型地域経営モデルに関する事例的研究, 農村計画学会誌, 30 (3), pp. 436-442, 2011. 12 
6）劉鶴烈，千賀裕太郎：住民主導型集落づくりの起動期の実態に関する考 察，農村計画学会誌，21，pp. 193-198，2002.11

7）吉村彩, 広田純一：地域づくりにおける地域住民の主体性形成プロセス とその要因，農村計画学会誌， 25, pp. 305-310, 2006.12

8）早坂水智, 山田晴義: 英国におけるコミュニティ・ビジネス組織に関す る実態調査報告，総合政策，3(2)，pp. 177-196，2001.12

9）齋藤雪彦：英国における農村開発施策，食と緑の科学，62，pp. 53-58, 2008. 3

10）八木洋憲，福与徳文，筒井義冨，三橋伸夫，鎌田元弘：英国における住 民参加型農村振興の実態, 農業工学研究所技報, 204, pp. 15-22, 2006. 3

11）石川誠：イギリスにおける都市・農村計画制度の経緯と現状, 明治大学 農学部研究報告, 127, pp. 1-26, 2001.7

12）鈴木孝男, 櫻井常矢，野呂拓生：「新たな公」形成に向けたコミュニティ・ プランの策定と支援システムに関する研究, 平成 19 年度国土政策関係研 究支援事業研究成果報告書

13）佐藤順子：英国ブレア政権下のローカル・コミュニティを重視した政策の 動向, 聖隷クリストファー大学社会福祉学部紀要，3, pp. 59-68, 2005. 3

14）浅見良露, 西川芳昭: 市民参加のまちづくり英国編, 創成社, pp. 15-18, 2006. 5

15）西山康雄, 西山八重子：イギリスのガバナンス型まちづくり, 学芸出版 社, pp. 13-17, pp. 24-40, 2008. 4

16）財団法人自治体国際化協会ロンドン事務所：パートナーシップを活用し た地方自治体と政府の新たな関係，2007.8

17) Plunkett Foundation: Community-owned Village Shops: A Better Form of Business, 2011. 1

18) Plunkett Foundation: Model Rules for Community Ownership
19) Plunkett Foundation: Plunkett Foundation Annual Review 2009 20) Oxfordshire Rural Community Council: ORCC General Leaflet, 2010

21) Oxfordshire Rural Community Council: ORCC Setting Up A Community Shop, 2010. 12

22) Oxfordshire Rural Community Council: ORCC Village Shops Handbook, 2011. 4

23) NATURAL ENGLAND: Green Belts: A Greener Future, 2010.1

24）財団法人自治体国際化協会ロンドン事務所：英国の地方自治 2011 年改 訂版，pp. 19，2011.11

25）内閣府 : 社会的企業についての法人制度及び支援の在り方に関する海外 現地調査, pp. 2-35, 2011.3

26) 中島智人：社会的企業研究に関する一考察：ビジネス・モデルの視点か 5, 産業能率大学紀要, 第 31 巻, 第 2 号, (別刷 ), pp. 16-35, 2011.2

27）柿本国弘：英国の都市農村計画と過疎地域政策，八千代出版，2000. 12

28）八木洋憲, 福与徳文, 筒井義冨 : 英国における住民参加型農村振興の実 態，農業工学研究所技報，204, pp. 15-22, 2006.3

29）西村幸夫：都市保全計画，東京大学出版会，pp. 417-479, 2004.9

30）松井真理子：都市との関係における英国の農村政策の二つの新方向，四 日市大学総合政策学部論集, 1(1/2), pp. 1-22, 2002.3

31）中島恵理：英国の持続可能な地域づくり，学芸出版社， 2005.7

32）東海林孝男，小林英嗣：英国の政策転換にみるアジェンダ 21 の位置づ けとローカルアジェンダ 21 の取り組み, 日本建築学会北海道支部研究報 告集, (79), pp. 487-490, 2006.7

（2012年11月 3 日原稿受理，2013年 5 月31日採用決定） 